\title{
Kinetic studies on substitution of cis-diaqua-chloro-tris-(dimethyl sulphoxide)-ruthenium(II) complex with some dipeptides in aqueous medium
}

\author{
ARUP MANDAL, PARNAJYOTI KARMAKAR, SUBHASIS MALLICK, BIPLAB K BERA, \\ SUBALA MONDAL, SUMON RAY and ALAK K GHOSH* \\ Department of Chemistry, The University of Burdwan, Burdwan 713 104, India \\ e-mail: alakghosh2002@yahoo.co.in
}

MS received 29 November 2011; revised 21 January 2012; accepted 7 February 2012

\begin{abstract}
The kinetics of interaction between cis- $\left[\mathrm{RuCl}\left(\mathrm{Me}_{2} \mathrm{SO}\right)_{3}\left(\mathrm{H}_{2} \mathrm{O}\right)_{2}\right]^{+}$and some selected dipeptides such as glycyl glycine(gly gly), glycyl alanine(Gly-L-ala) and glycyl-L-leucine(gly leu) has been studied spectrophotometrically as a function of $\left[\mathrm{RuCl}\left(\mathrm{Me}_{2} \mathrm{SO}\right)_{3}\left(\mathrm{H}_{2} \mathrm{O}\right)_{2}^{+}\right]$, [dipeptide] and temperature at a particular $\mathrm{pH}(5.0)$, where the substrate complex exists predominantly as a diaqua species (in aqueous solution) and dipeptides as the zwitter ions. The reaction has been found to proceed via two distinct consecutive steps i.e., it shows a non-linear dependence on the concentration of dipeptide: first process is dependent and the second step is independent of ligand concentration respectively. The rate constants for the processes are: $\mathrm{k}_{1} \sim 10^{-3} \mathrm{~s}^{-1}$ and $\mathrm{k}_{2} \sim 10^{-5} \mathrm{~s}^{-1}$. The activation parameters were calculated from Eyring plots suggests an associative mechanism for the interaction process. From the temperature dependence of the outer sphere association equilibrium constants, the thermodynamic parameters were also calculated, which gives a negative $\Delta \mathrm{G}^{0}$ value at all temperatures studied, supporting the spontaneous formation of an outer sphere association complex.
\end{abstract}

Keywords. Ligand substitution; dipeptides; cis- $\left[\mathrm{RuCl}\left(\mathrm{Me}_{2} \mathrm{SO}\right)_{3}\left(\mathrm{H}_{2} \mathrm{O}\right)_{2}\right]^{+}$; kinetics.

\section{Introduction}

Carcinostatic properties of platinum complexes, especially of cis-platin, ${ }^{1}$ involve special impetus to research on interaction of the metal ion with nucleic acid constituents. ${ }^{2-4}$ Ruthenium, rhodium, iridium and palladium complexes have also been reported to have considerable antibacterial behaviour. ${ }^{5,6}$ Of them, ruthenium complexes seem to be less toxic than cis-platin. ${ }^{7,8}$ Different studies reveal that a number of ruthenium compounds serve as bacterial mutagens and are capable of damaging genetic material. ${ }^{9-13}$ The in vivo generation of mixed aqua-ammineruthenium(II) from the ruthenium(III) prodrug should be favoured in a relatively reducing and hypoxic environment provided by the interior of many tumours. Antitumour, ${ }^{14-17}$, antiherpes, ${ }^{18}$ anti-HIV, ${ }^{19}$ antiamebic,${ }^{20}$ anticancer, ${ }^{21-25}$ antileukemic $^{26}$ and antifungal activity ${ }^{27,28}$ are observed in a series of ruthenium complexes.

In continuation of our earlier studies, ${ }^{29}$ we report here the interaction of some dipeptides with a different set of donor atoms.

*For correspondence

\section{Experimental}

The reactant cis- $\left[\mathrm{Ru}\left(\mathrm{Me}_{2} \mathrm{SO}\right)_{4} \mathrm{Cl}_{2}\right]$ was prepared and characterized according to the method reported by Evans et al. ${ }^{30}$ The substrate complex $\left[\mathrm{RuCl}\left(\mathrm{Me}_{2} \mathrm{SO}\right)_{3}\left(\mathrm{H}_{2} \mathrm{O}\right)_{2}\right]^{+}$(1) was prepared in situ by dissolving the above reactant complex in the aqueous solution (scheme 1). ${ }^{31}$

Cis- $\left[\mathrm{Ru}\left(\mathrm{Me}_{2} \mathrm{SO}\right)_{4} \mathrm{Cl}_{2}\right]$ once dissolved in water, immediately releases the O-bonded dimethyl sulfphoxide molecule. ${ }^{32}$

The products (2) of the reaction between the substrate complex and diglycine was prepared by mixing different molar ratios of reactants, viz., 1:1, 1:2 and $1: 3$ at $\mathrm{pH} 5.0$ and thermostating the mixture at $50^{\circ} \mathrm{C}$ for $72 \mathrm{~h}$. The absorption spectra of the resultant solutions were recorded using an aqueous ligand solution of appropriate molarity in the reference cell, and it was found that the maximum spectral difference between the product complex and the substrate complex, $\left[\mathrm{RuCl}\left(\mathrm{Me}_{2} \mathrm{SO}\right)_{3}\left(\mathrm{H}_{2} \mathrm{O}\right)_{2}\right]^{+}$(1) was observed at $257 \mathrm{~nm}$ (figure 1). The product composition was checked by Job's method of continuous variation as shown in figure 2 and was found to have a 1:1 metal:ligand ratio in the product. The $\mathrm{pH}$ was adjusted 


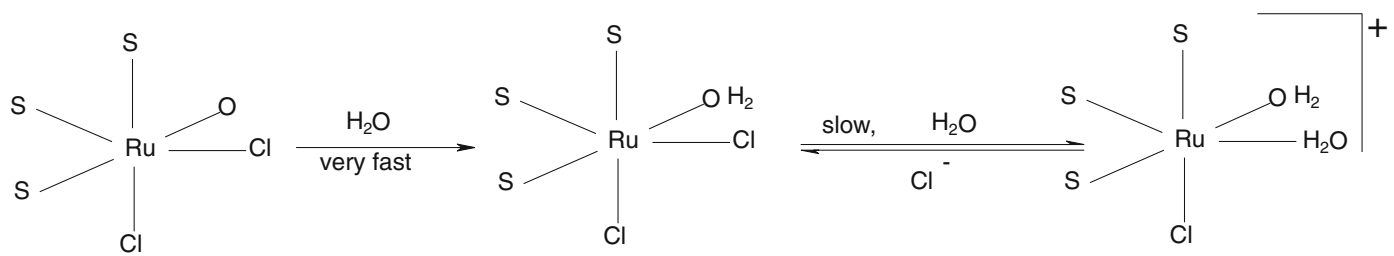

Scheme 1. Chemical behaviour of $c i s-\left[\mathrm{Ru}\left(\mathrm{Me}_{2} \mathrm{SO}\right)_{4} \mathrm{Cl}_{2}\right]$ in aqueous medium.

by adding a very small amount of dilute $p$-toluene sulphonic acid and $\mathrm{NaOH}$ solution such that the concentration of the reaction mixture remains constant. Measurement of $\mathrm{pH}$ were carried out with the help of a Sartorius digital pH meter (model PB-11) with an accuracy of \pm 0.01 units. Doubly distilled water was used to prepare all the solutions. All chemicals used were of AR grade.

Complex (1) and diglycine were mixed in 1:1 molar ratio at $\mathrm{pH} 5.0$ and a yellowish product was obtained. The IR spectra of the yellowish product in the $\mathrm{KBr}$ disc show strong band at $3435 \mathrm{~cm}^{-1}$ together with medium bands at 1630 and $626 \mathrm{~cm}^{-1}$. The strong band at $3435 \mathrm{~cm}^{-1}$ indicates that product is hydrated. The asymmetric $\mathrm{COO}^{-}$stretching frequency of the dipeptides occurs at $1580-1660 \mathrm{~cm}^{-1}$ when the group is coordinated to metals, whereas a non-coordinated $\mathrm{COO}^{-}$ group has the $\gamma_{\text {sym }}\left(\mathrm{COO}^{-}\right)$stretching at lower frequency. The band at $1630 \mathrm{~cm}^{-1}$ is therefore assigned to the $\gamma_{\text {asym }}\left(\mathrm{COO}^{-}\right)$of the metal-bounded carboxyl group. An intense band of the amide $(>C=O)$ in the non-coordinated diglycine undergoes a bathochromic $\sim 35 \mathrm{~cm}^{-1}$ shift in the IR spectra upon complexation. This is probably due to the involvement of the peptide nitrogen (because of the deprotonation that has taken place) in bonding with $\mathrm{Ru}(\mathrm{II})$, which lowers the bond order of the ( $>\mathrm{C}=\mathrm{O}$ ) amide group due to resonance stabilization. ${ }^{33}$ The $626 \mathrm{~cm}^{-1}$ is due to the formation of $\mathrm{Ru}-\mathrm{N}$ bond in the product. ${ }^{34}$

Conductance measurement also helps us to assign the product formation. With the progress of the reaction there is release of $-\mathrm{H}^{+}$ion (figure 9) and it is expected that the conductance of the reacting solution increases with the progress of the reaction and this is observed experimentally. Due to the release of $-\mathrm{H}^{+}$ion, the $\mathrm{pH}$ of the resulting solution is found to decrease.

\section{Kinetic studies}

Kinetic measurements and calculations were carried out in a similar way as reported in an earlier paper. ${ }^{29}$ The $\mathrm{k}_{1(\mathrm{obs})}$ and $\mathrm{k}_{2 \text { (obs) }}$ values were calculated graphically using the method of Weyh and Hamm. ${ }^{35}$

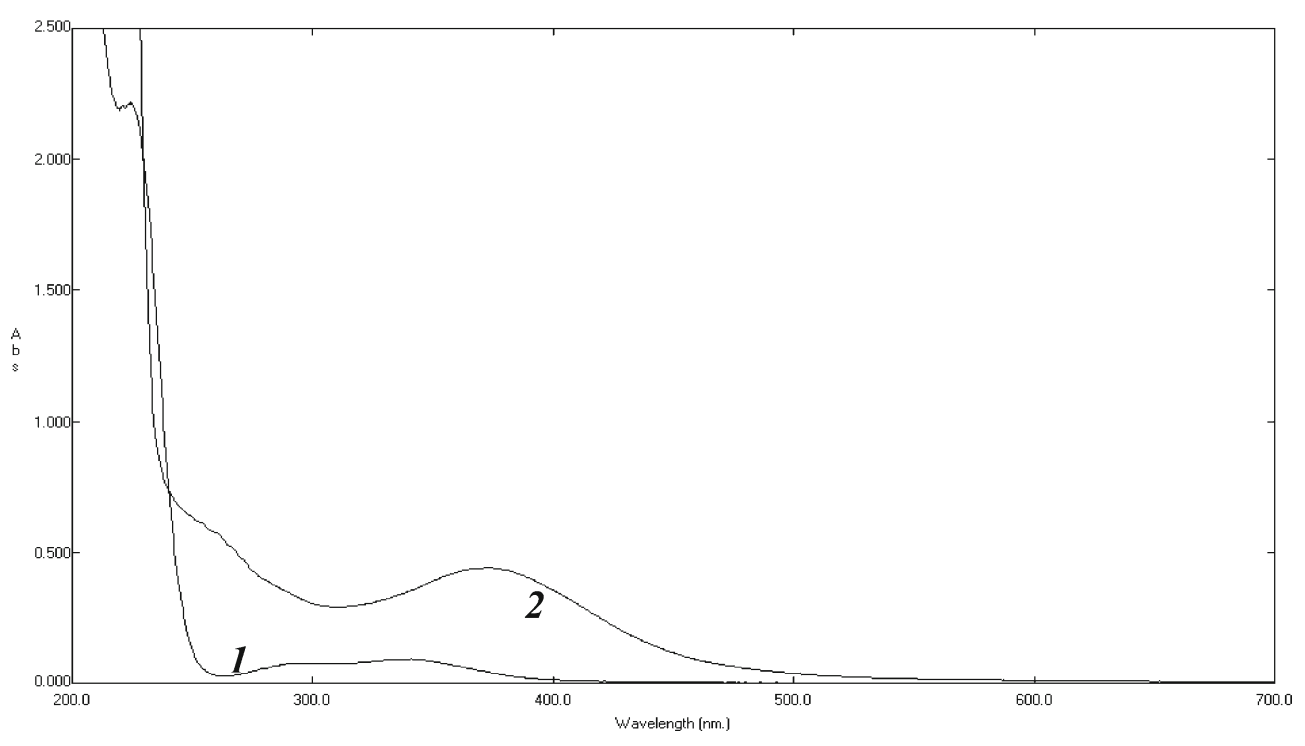

Figure 1. Spectral difference between substrate complex and product. (1) $\left[\mathrm{RuCl}\left(\mathrm{Me}_{2} \mathrm{SO}\right)_{3}\left(\mathrm{H}_{2} \mathrm{O}\right)_{2}^{+}\right]=1.0 \times 10^{-4} \mathrm{~mol} \mathrm{dm}^{-3} ;(2)\left[\mathrm{RuCl}\left(\mathrm{Me}_{2} \mathrm{SO}\right)_{3}\left(\mathrm{H}_{2} \mathrm{O}\right)_{2}^{+}\right]=1.0 \times$ $10^{-4} \mathrm{~mol} \mathrm{dm}^{-3}$, [gly gly] $=2.0 \times 10^{-3} \mathrm{~mol} \mathrm{dm}^{-3}, \mathrm{pH}=5.0$. 


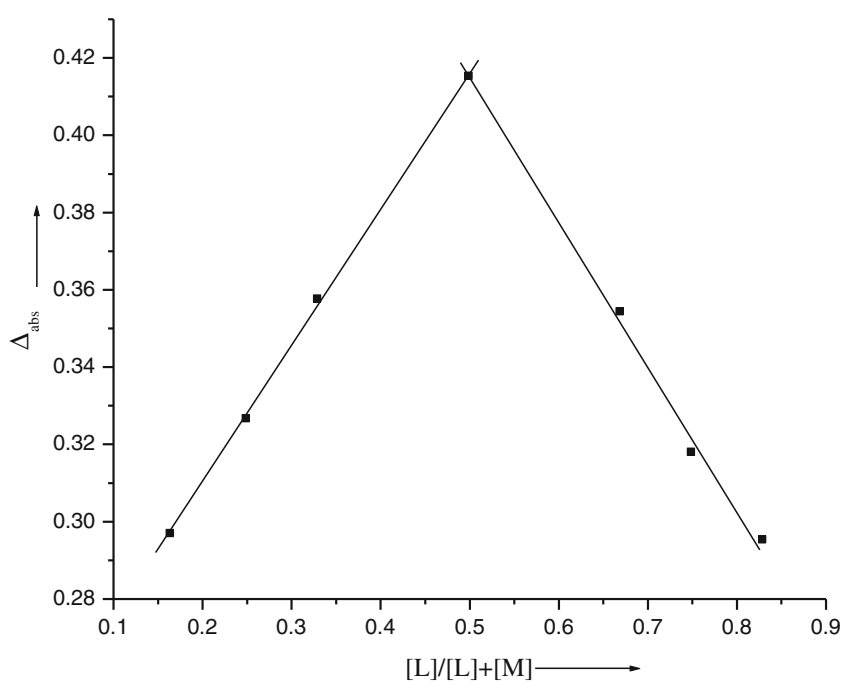

Figure 2. Job's plot: $\left[\mathrm{RuCl}\left(\mathrm{Me}_{2} \mathrm{SO}\right)_{3}\left(\mathrm{H}_{2} \mathrm{O}\right)_{2}^{+}\right]=1.0 \times$ $10^{-4} \mathrm{~mol} \mathrm{dm}^{-3}$, [diglycine] $=1.0 \times 10^{-4} \mathrm{~mol} \mathrm{dm}^{-3}$, $\mathrm{pH}=5.0$.

\section{Results and discussion}

The $\mathrm{pK}_{\mathrm{a}}$ values of the ligands (gly gly), (gly ala) and (gly leu) are $3.21,8.13,,^{36,37} 3.07,8.12^{38}$ and 3.18 , $8.14,{ }^{39}$ respectively at $25^{\circ} \mathrm{C}$. From the $\mathrm{pK}_{\mathrm{a}}$ values of all the ligands we can say that at $\mathrm{pH} 5.0$, all these three ligands remain in the zwitter ionic form.

The $\ln \left(\mathrm{A}_{\infty}-\mathrm{A}_{\mathrm{t}}\right)$ versus time, $(\mathrm{t})$ plot indicates that the reaction is not a single step process and a two step consecutive process may be assumed.

The rate constant for such a process can be evaluated by assuming the following scheme.
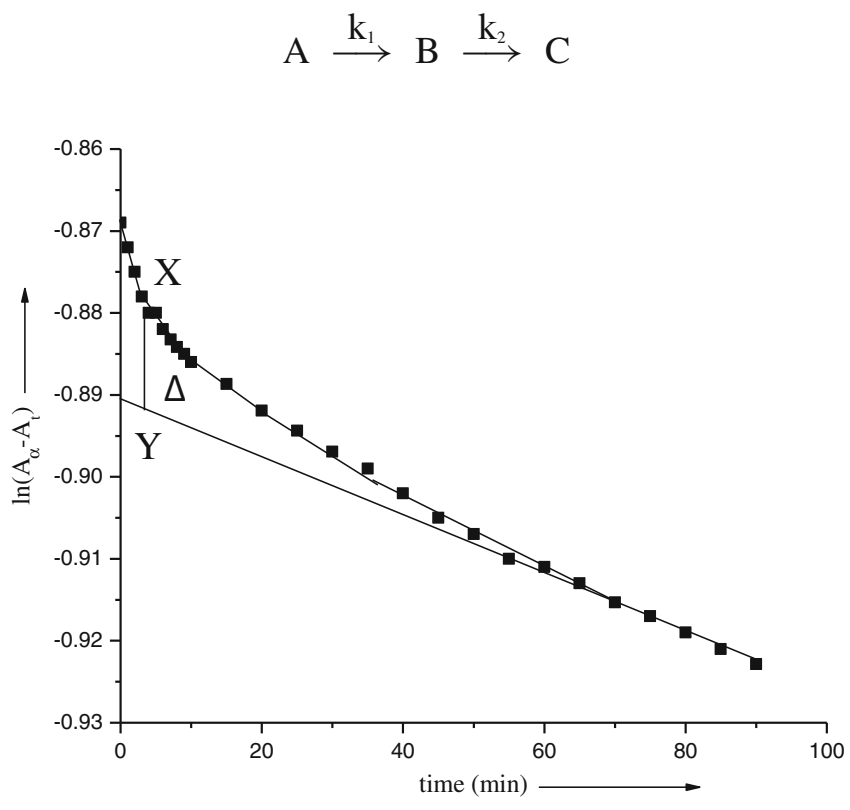

Figure 3. A typical plot of $\ln \left(\mathrm{A}_{\infty}-\mathrm{A}_{t}\right)$ versus time $\mathrm{t}$. $\left[\mathrm{RuCl}\left(\mathrm{Me}_{2} \mathrm{SO}\right)_{3}\left(\mathrm{H}_{2} \mathrm{O}\right)_{2}^{+}\right]=1.0 \times 10^{-4} \mathrm{~mol} \mathrm{dm} \mathrm{dm}^{-3}$, [diglycine] $=2.0 \times 10^{-3} \mathrm{~mol} \mathrm{dm}^{-3}, \mathrm{pH}=5.0, \mathrm{~T}=50^{\circ} \mathrm{C}$.

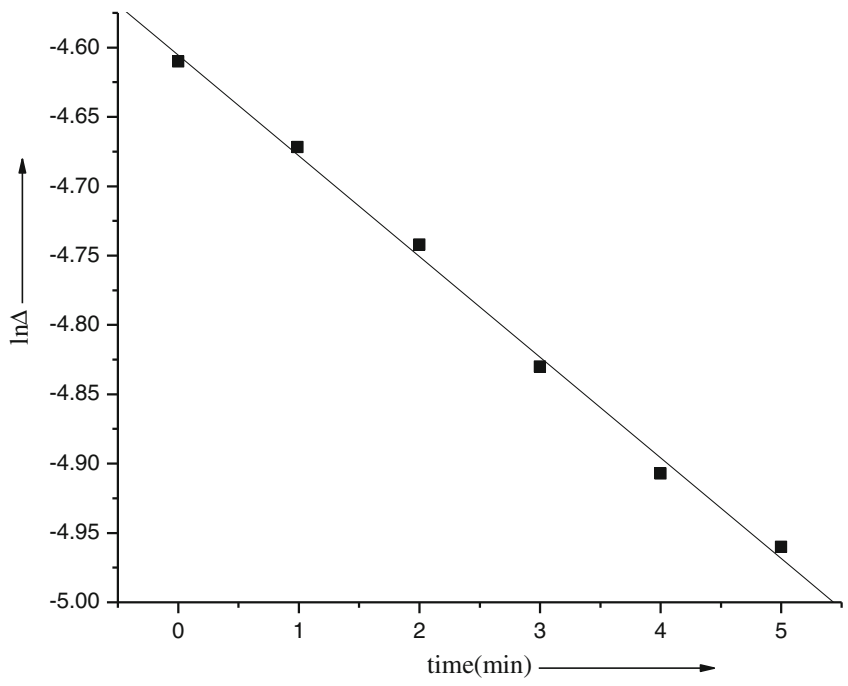

Figure 4. A typical plot of $\ln \Delta$ versus time $t$. $\left[\mathrm{RuCl}\left(\mathrm{Me}_{2} \mathrm{SO}\right)_{3}\left(\mathrm{H}_{2} \mathrm{O}\right)_{2}^{+}\right]=1.0 \times 10^{-4} \mathrm{~mol} \mathrm{\textrm {dm } ^ { - 3 }}$, [diglycine] $=2.0 \times 10^{-3} \mathrm{~mol} \mathrm{dm}^{-3}, \mathrm{pH}=5.0, \mathrm{~T}=50^{\circ} \mathrm{C}$.

A is the substrate complex, B is the intermediate with ligand diglycine and $\mathrm{C}$ is the final product complex $\left[\mathrm{Ru}\left(\mathrm{Me}_{2} \mathrm{SO}\right)_{3}(\mathrm{Cl})(\mathrm{L})\right]$.

\subsection{Calculation of $k_{1}$ value for $A \rightarrow B$ step}

The rate constant, $\mathrm{k}_{1(\mathrm{obs})}$ for $\mathrm{A} \rightarrow \mathrm{B}$ step can be evaluated by the method of Weyh and Hamm using the usual consecutive rate law:

$$
\begin{gathered}
\left(A_{\infty}-A_{t}\right)=a_{1} \exp \left(-k_{1(\text { obs })} t\right)+a_{2} \exp \left(-k_{2} t\right) \\
\text { or } \\
\left(A_{\infty}-A_{t}\right)-a_{2} \exp \left(-k_{2} t\right)=a_{1} \exp \left(-k_{1(\text { obs })} t\right) .
\end{gathered}
$$

Table 1. $10^{3} \mathrm{k}_{1(\mathrm{obs})}$ values for different ligand concentrations at different temperatures. [Complex-1] $=1.0 \times 10^{-4}$ $\mathrm{mol} \mathrm{dm}{ }^{-3}, \mathrm{pH}=5.0$.

\begin{tabular}{lcccccc}
\hline Ligand & Temperature & \multicolumn{5}{c}{$10^{3}$ [ligand] $\left(\mathrm{mol} \mathrm{dm}^{-3}\right)$} \\
\cline { 3 - 7 } & & 1.00 & 2.00 & 3.00 & 4.00 & 5.00 \\
\hline \multirow{2}{*}{ gly gly } & 35 & 0.86 & 1.46 & 1.98 & 2.43 & 2.78 \\
& 40 & 1.14 & 1.96 & 2.58 & 3.13 & 3.70 \\
& 45 & 1.50 & 2.60 & 3.35 & 4.00 & 4.40 \\
gly ala & 50 & 1.92 & 3.40 & 4.18 & 4.81 & 5.25 \\
& 35 & 0.80 & 1.29 & 1.70 & 2.34 & 2.50 \\
& 40 & 1.18 & 1.86 & 2.78 & 3.03 & 3.50 \\
gly leu & 45 & 1.58 & 2.56 & 3.33 & 4.10 & 4.40 \\
& 50 & 1.90 & 3.10 & 4.40 & 5.18 & 5.58 \\
& 45 & 1.10 & 1.86 & 2.40 & 2.75 & 2.95 \\
& 40 & 1.35 & 2.12 & 2.66 & 3.10 & 3.25 \\
& 45 & 1.55 & 2.68 & 3.10 & 3.60 & 3.81 \\
& 50 & 2.00 & 2.95 & 3.45 & 3.93 & 4.10
\end{tabular}




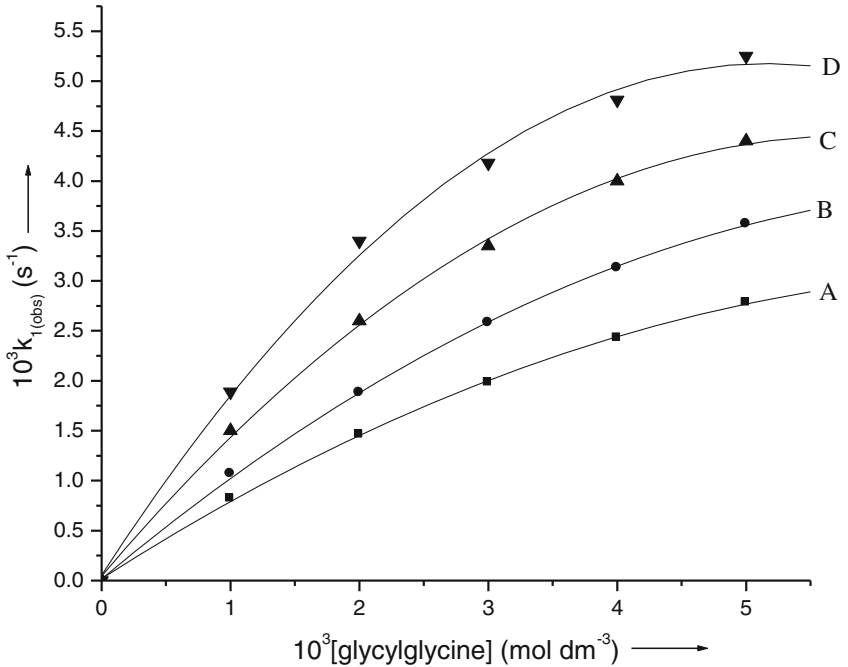

Figure 5. Plot of $\mathrm{k}_{1(\mathrm{obs})}$ versus [diglycine] at different temperatures. $\mathrm{A}=35, \mathrm{~B}=40, \mathrm{C}=45$, and $\mathrm{D}=50^{\circ} \mathrm{C}$.

Where $\mathrm{a}_{1}$ and $\mathrm{a}_{2}$ are constants dependent upon the rate constant and extinction coefficient. Values of $\left[\left(\mathrm{A}_{\infty}-\mathrm{A}_{t}\right)\right.$ $\left.-\mathrm{a}_{2} \exp \left(-\mathrm{k}_{2} \mathrm{t}\right)\right]$ are obtained from $\mathrm{X}-\mathrm{Y}$ at different time (t) (figure 3). So $\ln \Delta=$ constant $-\mathrm{k}_{1(\mathrm{obs})}$ t. $\mathrm{k}_{1(\mathrm{obs})}$ is derived from the slope of the $\ln \Delta$ versus $\mathrm{t}$ (where $\mathrm{t}$ is small) (figure 4). A similar procedure is applied for each ligand concentration in the $1.00 \times 10^{-3} \mathrm{~mol} \mathrm{dm}^{-3}$ to $5.00 \times 10^{-3} \mathrm{~mol} \mathrm{dm}^{-3}$ range, at constant $[(\mathbf{1})]\left(1.0 \times 10^{-4}\right.$

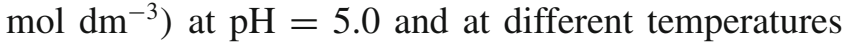
viz. $35,40,45$ and $50^{\circ} \mathrm{C}$, respectively. The $\mathrm{k}_{1(\mathrm{obs})}$ values are listed in table 1 .

The rate increases with increase in [ligand] and reaches a limiting value (figure 5), which is probable due to the completion of the outersphere association complex formation. Since the metal ion reacts with the immediate environment, further change in [ligand] beyond the saturation point will not affect the reaction rate and a gradual approach towards limiting rate is observed. At this stage, the interchange of the ligands from outer sphere to the inner sphere occurs,
Table 2. $10^{3} \mathrm{k}_{1(\mathrm{obs})}$ and $\mathrm{K}_{\mathrm{E} 1}$ values at different temperatures.

\begin{tabular}{lccc}
\hline Ligand & $\begin{array}{c}\text { Temperatures } \\
\left({ }^{\circ} \mathrm{C}\right)\end{array}$ & $\begin{array}{c}10^{3} \mathrm{k}_{1} \\
\left(\mathrm{~s}^{-1}\right)\end{array}$ & $\begin{array}{c}\mathrm{K}_{\mathrm{E} 1} \\
\left(\mathrm{dm}^{-3} \mathrm{~mol}^{-1} \mathrm{~s}^{-1}\right)\end{array}$ \\
\hline Gly gly & 35 & 5.89 & 170 \\
& 40 & 7.62 & 175 \\
& 45 & 8.77 & 206 \\
Gly ala & 50 & 9.76 & 249 \\
& 35 & 4.96 & 189 \\
& 40 & 6.66 & 213 \\
Gly leu & 45 & 7.94 & 247 \\
& 50 & 8.76 & 285 \\
& 35 & 2.35 & 131 \\
& 40 & 3.05 & 152 \\
& 45 & 3.85 & 175 \\
& 50 & 4.24 & 204 \\
\hline
\end{tabular}

i.e., diglycine attacks the $\mathrm{Ru}(\mathrm{II})$ atom of the substrate complex and forms the intermediate.

Based on scheme 2 a rate expression can be derived for $\mathrm{A} \rightarrow \mathrm{B}$ step.

$$
\begin{gathered}
\mathrm{d}[\mathrm{B}] / \mathrm{dt}=\mathrm{k}_{1} \mathrm{~K}_{\mathrm{E} 1}[\mathrm{~B}][\text { ligand }] /\left(1+\mathrm{K}_{\mathrm{E} 1}[\text { ligand }]\right) \\
\mathrm{d}[\mathrm{B}] / \mathrm{dt}=\mathrm{k}_{1 \text { (obs) }}[\mathrm{B}]_{\mathrm{T}}
\end{gathered}
$$

$\mathrm{T}$ stands for total concentration of $\mathrm{Ru}(\mathrm{II})$. Thus it can be written,

$$
\left.\mathrm{k}_{1(\mathrm{obs})}=\mathrm{k}_{1} \mathrm{~K}_{\mathrm{E} 1}[\text { ligand }] /\left(1+\mathrm{K}_{\mathrm{E} 1} \text { [ligand }\right]\right),
$$

where $k_{1}$ is the rate constant for the formation of intermediate (B) from the substrate complex, cis$\left[\mathrm{RuCl}\left(\mathrm{Me}_{2} \mathrm{SO}\right)_{3}\left(\mathrm{H}_{2} \mathrm{O}\right)_{2}\right]^{+}(\mathrm{A}) . \mathrm{K}_{\mathrm{E} 1}$ is the outersphere association equilibrium constant.

The equation can be written as

$$
1 / \mathrm{k}_{1(\mathrm{obs})}=1 / \mathrm{k}_{1}+1 / \mathrm{k}_{1} \mathrm{~K}_{\mathrm{E} 1} \text { [ligand]. }
$$

The plot of $1 / \mathrm{k}_{1(\mathrm{obs})}$ versus $1 /$ [ligand] should be linear (figure 6) with an intercept of $1 / \mathrm{k}_{1}$ and slope $1 / \mathrm{k}_{1} \mathrm{~K}_{\mathrm{E} 1}$.

\section{A.ligand}

(outer sphere association complex)

$$
\text { A.ligand } \quad \rightarrow \quad \text { B }
$$

Scheme 2. Schematic representation for $A \rightarrow B$. 


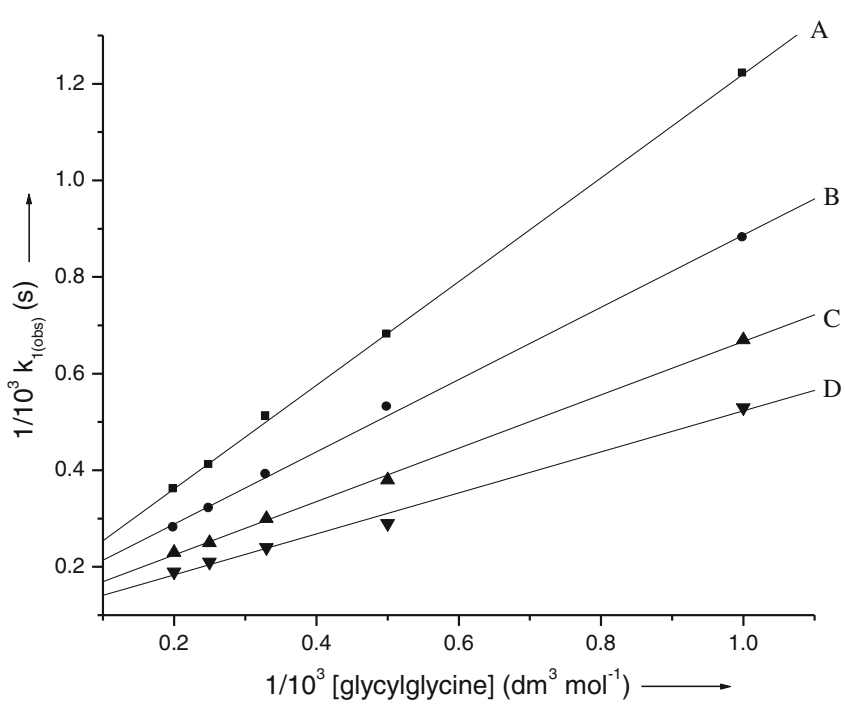

Figure 6. Plot of $1 / \mathrm{k}_{1 \text { (obs) }}$ versus $1 /$ [diglycine] at different temperatures, $\mathrm{A}=35, \mathrm{~B}=40, \mathrm{C}=45$, and $\mathrm{D}=50^{\circ} \mathrm{C}$.

The $\mathrm{k}_{1}$ and $\mathrm{K}_{\mathrm{E}}$ values obtained from the intercept and from slope to intercept ratios are given in table 2 .

\subsection{Calculation of $k_{2}$ for $B \rightarrow C$ step}

The $\mathrm{B} \rightarrow \mathrm{C}$ step is intramolecular ring closure and is independent of ligand concentration. At a particular temperature the slope of $\ln \left(\mathrm{A}_{\infty}-\mathrm{A}_{\mathrm{t}}\right)$ versus time plot at different ligand concentrations was found to be constant in the region where the plot is linear (figure 3). For different temperatures the $\mathrm{k}_{2}$ values are obtained directly from the limiting slope and the average $10^{5} \mathrm{k}_{2}$ values were $\left(4.54,6.35,8.72\right.$ and $\left.11.03 \mathrm{~s}^{-1}\right),(4.45,6.23,8.33$, $\left.10.24 \mathrm{~s}^{-1}\right)$ and $(3.50,5.89,7.92,10.16$ unit) for glycyl glycine, glycyl alanine and glycyl-L-leucine at 35, 40, 45 and $50^{\circ} \mathrm{C}$, respectively.

\subsection{Effect of temperature on the reaction rate}

Four different temperatures with varied ligand concentrations were chosen and the results are listed in table 3. The activation parameters for the step $\mathrm{A} \rightarrow \mathrm{B}$ and $\mathrm{B} \rightarrow$

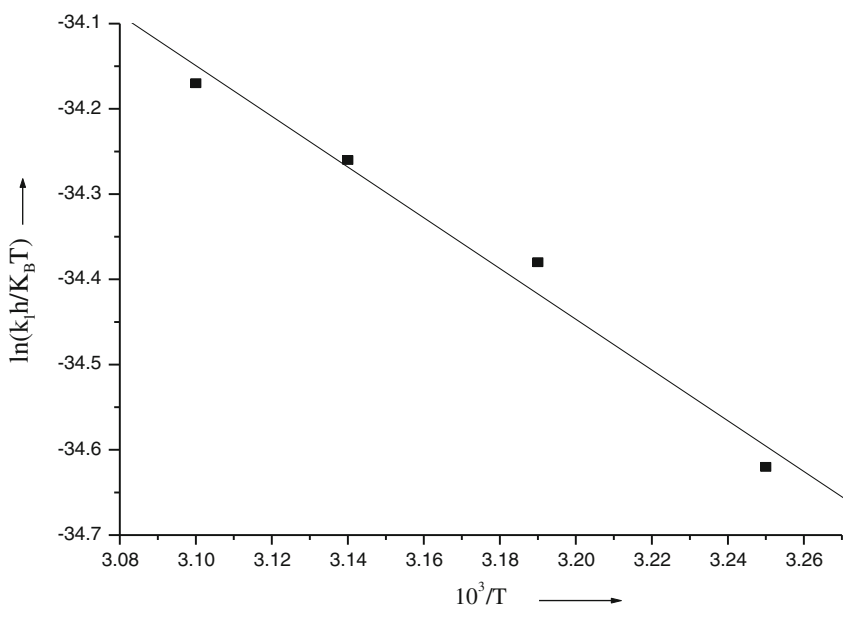

Figure 7. Eyring plot $\left(\ln _{1} \mathrm{~h} / \mathrm{k}_{\mathrm{B}} \mathrm{T}\right.$ versus $\left.1 / \mathrm{T}\right)$ for the step $\mathrm{A} \rightarrow \mathrm{B}$ (gly gly).

$\mathrm{C}$ are evaluated from the linear Eyring plots (figures 7 and 8).

The low $\Delta \mathrm{H}^{\neq}$values are in support of the ligand participation in the transition state for both steps. The positive energy required for the bond breaking process is partly compensated for by the negative energy obtained from bond formation in the transition state and, hence, a low value of $\Delta H^{\neq}$is observed. The highly negative $\Delta S^{\neq}$values, on the other hand, suggest a more compact transition state than the starting complexes and this is also in support of the assumption of a ligand participated transition state. $\Delta \mathrm{H}_{2}^{\neq}$is higher than $\Delta \mathrm{H}_{1}^{\neq}$which is quite expected for the second step which is slower than the first step.

\section{Mechanism and conclusion}

Our results indicate that the first step i.e., the attack by the incoming ligand (diglycine) proceed by an associative interchange (Ia) mechanism. This prediction is supported by the following facts. First, with an increase in ligand concentration saturation in rate is observed. This is possible only when an outer sphere association complex is formed. Secondly, the low enthalpy of

Table 3. Activation parameters for [complex-1] by diglycine in aqueous medium, $\mathrm{pH}=5.0$.

\begin{tabular}{lccccc}
\hline Ligand & $\Delta \mathrm{H}_{1}^{\neq}\left(\mathrm{kJ} \mathrm{mol}^{-1}\right)$ & $\Delta \mathrm{S}_{1}^{\neq}\left(\mathrm{J} \mathrm{K}^{-1} \mathrm{~mol}^{-1}\right)$ & $\Delta \mathrm{H}_{2}^{\neq}\left(\mathrm{k} \mathrm{J} \mathrm{mol}^{-1}\right)$ & $\Delta \mathrm{S}_{2}^{\neq}\left(\mathrm{J} \mathrm{K}^{-1} \mathrm{~mol}^{-1}\right)$ & ref. \\
\hline Azide & $20.1 \pm 3.49$ & $-162 \pm 11$ & $35.5 \pm 4.2$ & $-105 \pm 13$ & 40 \\
gly gly & $24.7 \pm 2.6$ & $-207 \pm 8$ & $46.8 \pm 0.8$ & $-176 \pm 2$ & 29 \\
gly ala & $28.1 \pm 3.9$ & $-198 \pm 12$ & $52.6 \pm 2.45$ & $-154 \pm 7$ & This work \\
gly leu & $30.3 \pm 1.0$ & $-191 \pm 5$ & $56.0 \pm 3.95$ & $-148 \pm 12$ & This work \\
\hline
\end{tabular}




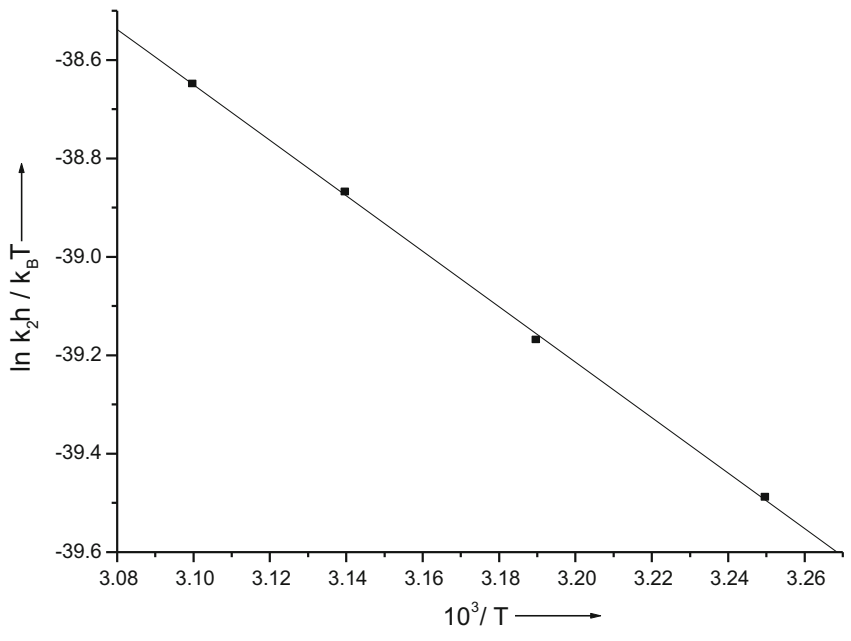

Figure 8. Eyring plot $\left(\ln \mathrm{k}_{2} \mathrm{~h} / \mathrm{k}_{\mathrm{B}} \mathrm{T}\right.$ versus $\left.1 / \mathrm{T}\right)$ for the step $\mathrm{B} \rightarrow \mathrm{C}$ (gly gly).

activation and large negative value of entropy of activation strongly suggest the ligand participation in the transition state. In the first step, a rapid equilibrium is established, resulting in outer sphere complex (ion pair) between complex-1 and ligand diglycine. Then the ionpair is transformed to mono bonded complex which is the rate limiting first step $\left(\mathrm{k}_{1}\right)$. The second step is the intramolecular ring closure which is independent of the incoming ligand concentration. This is supported by the values of rate constant $\left(\mathrm{k}_{2}\right)$; for this step $\mathrm{k}_{2}$ values were found to be independent of ligand concentration. From the temperature dependence of the $\mathrm{K}_{E 1}$, the thermodynamic parameters are calculated: $\Delta \mathrm{H}_{1}^{0}=21.0 \pm 5.3$, $20.4 \pm 1.8,21.2 \pm 1.6 \mathrm{~kJ} \mathrm{~mol}^{-1}$ and $\Delta \mathrm{S}_{1}^{0}=111 \pm 14$, $135 \pm 6,137 \pm 5 \mathrm{~J} \mathrm{~K}^{-1} \mathrm{~mol}^{-1}$.

From IR spectra, it was seen that $-\mathrm{COO}^{-}$is involved in complexation through $\mathrm{O}^{-}$centre and amide $-\mathrm{NH}$ centre. As the electron density on $\mathrm{O}^{-}$is greater than that of amide $\mathrm{N}$ centre, $\mathrm{O}^{-}$follows $\mathrm{k}_{1}$ path and $\mathrm{N}$ follows $\mathrm{k}_{2}$ path. The final product is a five membered chelate involving the carboxylate $\left(\mathrm{O}^{-}\right)$and amide $(\mathrm{N})$ centres of the dipeptides.

From a comparison of the dipeptides used, it can be concluded that the variation in size and bulkiness of the coordinating dipeptides indicates their functional properties as nucleophiles. The sensitivity of the reaction rate towards the donor properties of the entering<smiles>[R]C(NC(=O)C[NH3+])NC(=O)OC(C)=[W]</smiles>

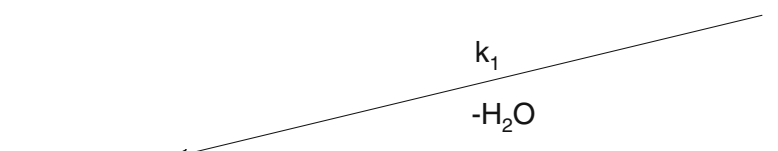

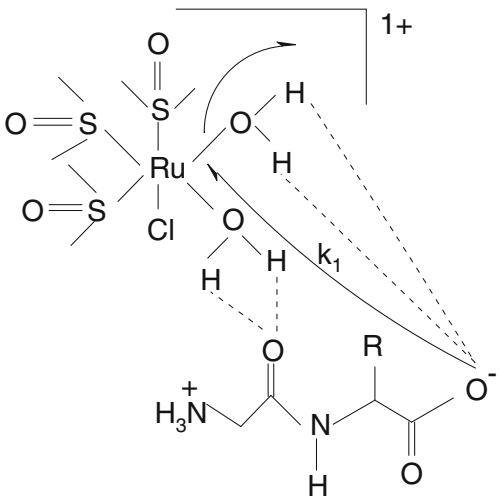

outer sphere complex

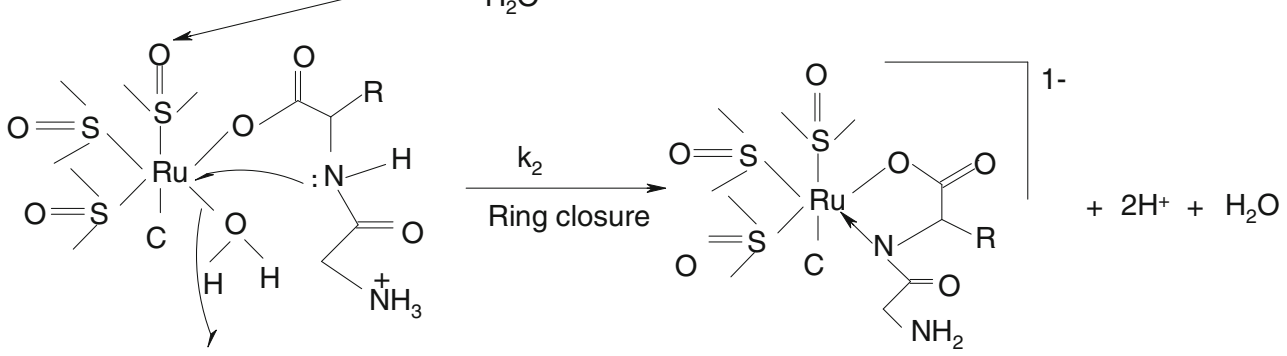

When $\mathrm{R}=\mathrm{H}$; the dipeptide is Gly-gly

$$
\begin{aligned}
& =\mathrm{CH}_{3} \text {; it is Gly-ala } \\
& =\mathrm{CH}_{2} \mathrm{CH}\left(\mathrm{CH}_{3}\right)_{2} \text {; it is Gly-leu }
\end{aligned}
$$

Figure 9. Plausible mechanism for the substitution of aqua ligands from $c i s-\left[\mathrm{RuCl}_{(}\left(\mathrm{Me}_{2} \mathrm{SO}\right)_{3}\left(\mathrm{H}_{2} \mathrm{O}\right)_{2}\right]^{+}$by dipeptides. 
ligands is in the line with that expected for an associative mode of activation. The differences in reactivity of the selected dipeptides is obvious and their reactivity follows the order Gly-L-leu < Gly-L-ala < Gly-gly. In addition, steric effects are very important as well. For the three dipeptides with increasing steric effects reactivity decreases which reflect in their rate constants values. So from IR data, conductance measurement and Job's plot a plausible mechanism may be shown in the following scheme (figure 9).

\section{Acknowledgements}

The authors acknowledge the assistance received from the University of Burdwan. One of the authors (AM) is indebted to the University Grants Commission (UGC), New Delhi, India for providing a fellowship to him. Authors are also indebted to Dr. P Chattopadhyay for his help in preparing the starting material.

\section{References}

1. Rosenberg B, Vancamp L and Krigas T 1965 Nature (London) 205698

2. Esposito B P and Najjar R 2002 Coord. Chem. Rev. 232 127

3. Banerjee D, Kadam T A and Sigal H 1981 Inorg. Chem. 202586

4. Umapathy P 1989 Coord. Chem. Rev. 95129

5. Clarke M J 1980 in: Martell A E (ed.), Inorg. Chem. in Biol. and Med., (ACS Symp. Ser. 140) Am. Chem. Soc., Wasington $D C, 157$ and references cited therein

6. Pruchnik P F, Bien M, Lakowicz T and Tadeusz 1996 Met. Based Drugs 4185

7. Clarke M J 1980 Met. Ions Biol. Syst. 11231

8. Yasbin R E, Matthews C R and Clarke M J 1980 Chem. Biol. Interact. 31355

9. Reedijk J 1987 Pure \& Appl. Chem. 59181

10. Zhao M and Clarke M J 1999 J. Biol. Chem. 4325

11. Galardon E, Maux P Lc, Bondon A and Simonncaux G 1999 Tetrahedron: Asymmetry 104203

12. Frasca D R and Clarke M J 1999 J. Am. Chem. Soc. 121 8523

13. Povsc V G and Olabe J A 1998 Transition Met. Chem. 23657

14. Izumi H K and Smith W L 2000 Abstracts of papers of the Am. Chem. Soc. 219727

15. Wang Z M and Ji L N 2002 Prog. Chem. 14296

16. Roncaroli F, Ruggiero M E, Franco D W, Estiu G L and Olabe J A 2002 Inorg. Chem. 415760
17. Harthmann M, Lipponer K-G and Keppler B K 1998 Inorg. Chim. Acta 267137

18. Turel I, Pecanac M, Golobic A, Allessio E and Serli B 2002 Eur. J. Inorg. Chem. 1928

19. Leudtke N W, Hwang J S, Glazer E C, Gut D, Kol M and Tor Y 2002 Chembiochem 3766

20. Shailendra Bharti N, Garza M T G, Guzvega D E, Garza J C, Saliem K, Naqv M and Zam A 2001 Bioorg. Med. Chem. Lett. 112675

21. Allessio E, Iengo E, Serli B, Mestroni G and Sava G 2001 J. Inorg. Biochem. 8621

22. Ang W H and Dyson P J 2006 Eur. J. Inorg. Chem. 20 4003

23. Clarke M J 2003 Coord. Chem. Rev. 236209

24. Komeda S, Moulaei T, Woods K K, Chikuma M, Farrell N P and Williams L D 2006 J. Am. Chem. Soc. 12816092

25. Hannon M J 2007 Chem. Soc. Rev. 36280

26. Pitteri C and Cini R 1998 J. Chem. Soc., Dalton Trans. 2679

27. Sulu M, Kucukbay H, Durmaz R and Gunal S 2000 Microbiologica 2373

28. Zhen Q X, Ye B H, Liu J G, Zhang Q L, Ji L N and Wang L 2000 Inorg. Chim. Acta 303141

29. Mandal A, Bera B K, Mallick S, Mondal S, Karmakar P and Ghosh A K 2011 Int. J. Life Sci. Pharma Res. 1 110

30. Evans I P, Spencer A and Wilkinson G $1973 \mathrm{~J}$. Am. Chem. Soc., Dalton Trans. 204

31. Enzo Alessio, Giovanni Mestroni, Giorgio Nardin, Wahib M. Attia, Mario Calligaris, Gianni Sava and Sonia Zoret 1988 Inorg. Chem. 274099

32. Barnes J R and Goodfellow R J 1976 J. Chem. Res., Miniprint 4301

33. Nath M, Pokharia S, Eng G, Song X and Kumar A 2004 Synthesis and reactivity in inorganic and metal-organic chemistry 341689

34. Mercer E E, McAllister W A and Durig J R 1966 Inorg. Chem. 51881

35. Weyh J A and Hamm R E 1969 Inorg. Chem. 8 2298

36. Kim M K and Martell A E 1984 Biochemistry 3 1169

37. Sigel H, Griesser R and Prijs B 1972 Z Naturforsch (B) 27353

38. Martell A E and Smith R M 1974 Critical Stability Constants, vol. 1 (New York, NY, USA: Plenum Press) 297

39. Martell A E and Smith R M 1974 Critical stability constants, vol. 1 (New York, NY, USA: Plenum Press) 299

40. Mandal A, Bera B K, Mallick S, Mondal S, Karmkar $\mathrm{P}$ and Ghosh A K 2010 Inorg. Chem. Indian J. 5(4) 176 